BIOMEDICA

Vol. 3 No. 1 y $2-1983$

\title{
TRANSMISION EXPERIMENTAL DEL VIRUS DE LA ENCEFALITIS EQUINA VENEZOLANA, SUBGRUPO ID, POR PSOROPHORA CONFINNIS A RATONES
}

\author{
ALBERTO MORALES, * MARGARITA ROMERO, ${ }^{\star \star}$ VICTOR ALBERTO OLANO. ${ }^{* \star \star}$
}

Se realizó un experimento con el objeto de investigar la capacidad del mosquito Psorophora confinnis para transmitir por picadura a ratones blanco-suizos de 21 días una cepa de virus de encefalitis equina venezolana, subgrupo ID.

Cuando los mosquitos se alimentaron sobre hamster con altas viremias $(7.5,6.5$ y 6.3 dex en $0.1 \mathrm{ml}$. de suero), los porcentajes de infección de los mosquitos y los de transmisión fueron altos.

Sin embargo, cuando los mosquitos se alimentaron sobre Proechimys hendei con viremias bajas $(1,4$ y 2.6 dex en $0.1 \mathrm{ml}$. de suero $)$ el porcentaje de infección de los mosquitos fue muy bajo y no hubo transmisión. Cuando la viremia en el Proechimys fue de 4.4 dex en 0.1 $\mathrm{ml}$. de suero, el porcentaje de infección de los mosquitos aumentó y hubo transmisión baja (9\%).

Los resultados sugieren que Psorophora confinnis es un mosquito que tiene un alto umbral de infección para EEV subgrupo ID.

\section{INTRODUCCION}

En un trabajo anterior demostramos que casi la totalidad de las hembras de Psorophora confinnis que se alimentaron en el laboratorio sobre hamsters con concentraciones altas de virus de la encefalitis equina venezolana, subgrupo ID, muestran el virus en la hemolinfa. En dicho trabajo, que se realizó como parte del estudio para apreciar la capacidad vectorial del Ps. confinnis, se examino la hemolinfa de mosquitos con períodos variables de incubación extrínseca; en el trabajo aludido se mostraron los resultados del intento de aislamiento de virus a partir de la hemolinfa de estos mosquitos. (1).
Los mosquitos a los cuales se les extrajo la hemolinfa habían picado inmediatamente antes a ratones blancos con el propósito de ver si a estos roedores les transmitían el virus. Ahora presentamos los resultados del intento de transmisión del virus por la picadura de los mosquitos a dichos ratones.

\section{MATERIALES Y METODOS}

Mosquitos:

Los mosquitos procedían de una colonia de Ps. confinnis (Arribalzaga, 1891) que se han mantenido en el Laboratorio de Entomología del Instituto Nacional de Salud en Bogotá y cuyos orígenes y métodos de mantenimiento,

\footnotetext{
* Bacteriólogo, M.Sc. Grupo de Entomología, Instituto Nacional de Salud (INS). Apartado aéreo 80334, Bogotá, Colombia, S.A.

** Bacterióloga, Grupo de Virología (INS)

*** Biólogo, Grupo de Entomología (INS).
} 
sistemas de alimentación antes y después de la comida infectante, así como los requerimientos de humedad, temperatura y edad de los mosquitos utilizados, son los mismos que se describieron en una publicación anterior (2).

\section{VIRUS}

Para la infección de los mosquitos se utilizó la cepa de virus de encefalitis equina venezolana INS 59001 (tipo enzoótico) aislada el 28 de junio de 1970 del cerebro de un hamster centinela expuesto en un bosque de la finca Riovista, vereda El Terminal, municipio Puerto Boyacá, en el valle del Magdalena Medio, Colombia y conservada liofilizada a $-70^{\circ} \mathrm{C}$; esta cepa se clasificó como perteneciente al sub-grupo antigénico ID en los laboratorios del Instituto Nacional de Salud de Colombia. La clasificación fue confirmada por el Laboratorio de Middle America Research Unit (MARU) de Panamá.

\section{Infección de los mosquitos:}

Para lograr la infección de los mosquitos se hizo que éstos, divididos en grupos convenientes, picaran a tres hamster y a dos Proechimys hendei experimentalmente infectados en el laboratorio con el virus EEV y con viremias variables en el momento de la picadura.

De un primer grupo de mosquitos que picó a un hamster (No. 1) con viremia de dex 7,5 por $0,1 \mathrm{ml}$. se examinaron ejemplares a los 6 , 7, 8, 9 y 11 días de incubación extrínseca. De un segundo grupo que se alimentó sobre otro hamster (No. 2) con viremia de 6,5 se examinaron mosquitos a los 11 y 13 días.

De un tercer grupo, alimentado sobre un tercer hamster, éste con viremia de 6,3 , se examinaron mosquitos también a los 11,12 y 13 días.

Los mosquitos alimentados sobre los Proechimys se examinaron así: un primer grupo se alimentó sobre el Proechimys No. 1 con viremia 2,6 que había sido inoculado 48 horas antes con el virus; este grupo se examinó a los 7 días de incubación extrínseca. Un segundo grupo se alimentó también sobre el Proechimys No. 1 pero un día más tarde, esto es a las 72 horas post-inoculación, cuando tenía una viremia de sólo 1,4 ; este segundo grupo se examinó a los 8 días de incubación. Un tercer grupo alimentado sobre el Proechimys No. 2, con viremia 4,4, se examinó a los 7, 8 y 10 días del período de incubación extrínseca. Este Proechimys había sido inoculado con el virus, 2 días antes de haber sido picado.

Los hamsters recibieron las siguientes dosis por vía subcutánea: No. 1 , dex 4,2, No. 2, 2,9 y No. 3, 2,9. Los Proechimys No. 1, 3,6 y No. 2, 3,8. Las dosis se calcularon de acuerdo al método de Reed y Muench (3) y expresado en "dex" (4).

El virus usado para los cinco animales fue el INS-59001.

Los mosquitos que se alimentaron sobre los animales virémicos, y que sobrevivieron, picaron en forma individual a ratones de 21 días normales (un mosquito para cada ratón) para hacer el ensayo de transmisión. Una vez que los mosquitos picaron a los ratones normales se les extrajo hemolinfa para buscar virus, de acuerdo con el trabajo anterior. Los ratones picados se observaron diariamente.

Al terminarse de extraer la hemolinfa, los mosquitos se congelaron a $-70^{\circ} \mathrm{C}$ y se conservaron a esta misma temperatura hasta el momento en que más tarde se examinaron para estudiar su contenido en virus.

Los ratones blanco-suizos que fueron picados por los mosquitos, se siguieron observando y a aquéllos que enfermaban o morían se les extraía el cerebro con el cual se inocularon tubos Vero para buscar la presencia de agentes citopatogénicos. En todos los tubos inoculados se observó efecto citopatogénico y de éstos se tomaron al azar 13 tubos que se probaron por FC con suero anti VEE siguiendo la técnica de Clark y Casals modificada por Sever (5).

En el cuadro No. 1 se indica la proporción de mosquitos que se infectó al alimentarse sobre el hamster virémico y que ya fue 
informada en el trabajo anterior. Se indican igualmente, lo que es el objeto de este trabajo, los resultados de los ensayos de transmisión hechos con los mismos mosquitos, excepto los mosquitos que no se probaron para presencia de virus en el mosquito.

En primer lugar -tal como se señaló antesllama la atención la gran capacidad del mosquito para infectarse con el virus. De los 51 ejemplares estudiados solo en 1 , con período de incubación de 9 días no se encontró virus.

En cuanto a capacidad transmisora, esta no se demostró en mosquitos con período de incubación extrínseco de 6 días, a pesar de

CUADRO № I

RESULTADO DEL INTENTO DE TRANSMISION DE VIRUS EEV SUBGRUPO ID POR MOSQUITOS PS. CONFINNIS A RATONES

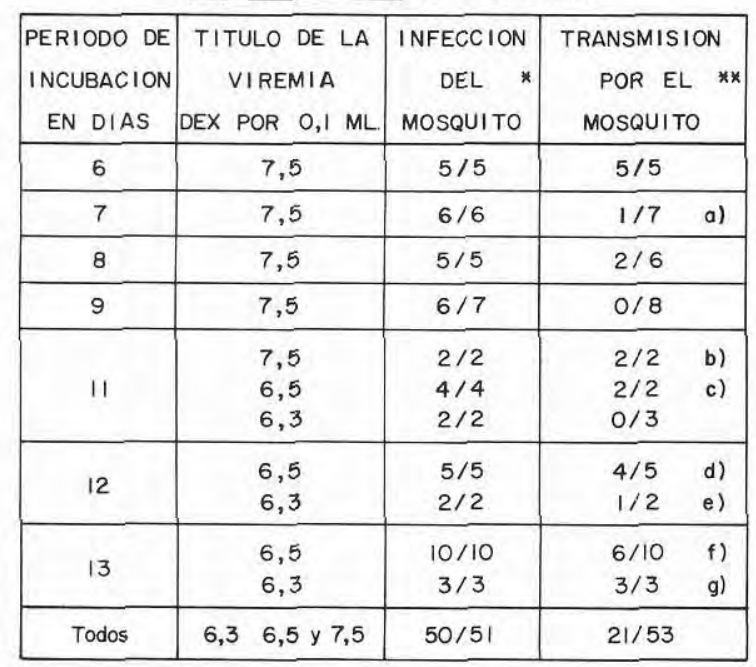

$x$ Mosquitos infectados con virus/Total de mosquitos alimentados sobre hamster virémicos.

xx Mosquitos que transmitieron el virus/Total de mosquitos alimentados sobre hamster virémicos.

Se consideró que el mosquito transmitió el virus cuando a picar a un ratón, después de los periodos de incubación extrinseco indicados, éste se paralizo y murio, habiéndose comprobado en su cerebro la presencia de un agente citopatogénico que destruía las células vero en 304 días. De los 21 ratones muertos se examino el cerebro por $F C$, previo pase por células VERO, en 12 habiéndose comprobado el EEV en todos 12, asi: en a) 1, en b) 2; en en c) 1 ; en e) 1 ; en f) 3 y en g) 3 . En los ratones restantes no se examinó el cerebro por FC. que los 5 mosquitos estudiados sí estaban comprobadamente infectados por el virus. Si bien el número de ejemplares es escaso, la conclusión es que, en las condiciones del experimento, cuando los mosquitos se alimentan sobre hamsters con niveles de viremia de 6,3 dex o superiores, el período de incubación extrínseco es superior a 6 días.

Con períodos de incubación de 7 o más días comienza a mostrarse ya la capacidad vectora del mosquito. No hay diferencias estadísticamente significativas según niveles de viremia $(6,3,6,5$ y 7,5$)$ aunque sí parece que la capacidad transmisora aumenta con el período de incubación extrínseco. En efecto, cuando éste es de 7 a 9 días, se observa que 3 mosquitos de 21 transmiten, esto es el $14 \%$.

Cuando el período de incubación es de 11 a 12 días la proporción de transmisiones positivas es del 67\% (18 entre 27). Esta diferencia es estadísiticamente significativa.

El cuadro No. 2 presenta los datos correspondientes a los mosquitos alimentados sobre Proechimys virémico. Sólo 22 de 47 mosquitos se infectaron y sólo 2 de 45 mosquitos transmitieron. Es entendible que en este caso una menor proporción de mosquitos se infectó $(46,8 \%)$ tal vez por haber picado el Proechimys cuando tenían evidentemente menos virus que los hamster cuando se hizo al experimento. Lo que no tiene explicación clara es que de 22 mosquitos comprobadamente infectados por el virus sólo 2 lo transmitieran. La única razón podría ser que por haberse infectado con pocas dosis de virus probablemente los mosquitos necesiten más de 10 días de incubación extrínseca para que el virus se concentre en las glándulas salivales en cantidad suficiente como para ser transmitido por picadura.

Llama la atención además que los Proechimys hubieran desarrollado viremias menos altas que los hamsters, aunque unos y otros hubieran recibido dosis infectantes sensiblemente iguales. Sin duda los hamsters son mejores multiplicadores del virus que los Proechimys. Como este es un reservorio natural habrá que colegirse que los vectores 
CUADRO № 2

\section{RESULTADO DEL INTENTO DE TRANSMISION DE VIRUS EEV SUBGRUPO ID POR MOSQUITOS PS. CONFINNIS A RATONES}

\begin{tabular}{|c|c|c|c|c|c|}
\hline \multicolumn{2}{|c|}{$\begin{array}{l}\text { PERIODO DE } \\
\text { INCUBACION } \\
\text { EN DIAS }\end{array}$} & \multicolumn{2}{|c|}{$\begin{array}{c}\text { TI TULO DE LA } \\
\text { VIREMIA }\end{array}$} & $\begin{array}{l}\text { I NFECCION } \\
\text { DEL * } \\
\text { MOSQUITO }\end{array}$ & $\begin{array}{l}\text { TRANSMISION } \\
\text { POR EL ** } \\
\text { MOSQUITO }\end{array}$ \\
\hline \multicolumn{2}{|r|}{7} & \multicolumn{2}{|r|}{$\begin{array}{l}2,6 \\
4,4\end{array}$} & $\begin{array}{l}6 / 15 \\
11 / 15\end{array}$ & $\begin{array}{l}0 / 16 \\
2 / 11 \quad a)\end{array}$ \\
\hline \multicolumn{2}{|r|}{8} & \multicolumn{2}{|r|}{$\begin{array}{l}1,4 \\
4,4\end{array}$} & $\begin{array}{l}0 / 7 \\
5 / 9\end{array}$ & $\begin{array}{l}0 / 7 \\
0 / 10\end{array}$ \\
\hline & 10 & \multicolumn{2}{|r|}{4,4} & $0 / 1$ & $0 / 1$ \\
\hline \multicolumn{2}{|c|}{ Todos } & 1,4 & 2,6 y 4,4 & $22 / 47$ & $2 / 45$ \\
\hline
\end{tabular}

x Mosquitos infectados con el virus/Total de mosquitos alimentados sobre Proechimys hendei virémicos.

$x$ Mosquitos que transmitieron el virus/Total de mosquitos alimentados sobre Proechimys virémicos.

Se consideró que el mosquito transmitió el virus cuando al picar a un ratón después de los periodos de incubación extrinseco indicados, este se paralizo y murio, habiéndose comprobado en su cerebro la presencia de un agente citopatogénico que destruia las células Vero en 3 o 4 dias. a) Los dos ratones que recibieron la picadura del mosquito murieron con sintomas de encefalitis. El cerebro de uno de ellos se examino por CF dando resultados positivos para VEE; el cerebro del ratón restante no se examino por CF pero produio efecto citopatogénico en células vero

naturales del virus enzoótico deben tener umbrales bajos de infección.

Es de notarse que de las 23 transmisiones consideradas como positivas sólo en 13 hubo demostración completa y definitiva de que el virus VEE se encontraba en el cerebro del ratón picado.

En los 10 ratones restantes que por distintas razones no se pudieron estudiar por FC, solo sabemos que los ratones se paralizaron y murieron y que de su cerebro se aisló un agente que produce evidente y dramático efecto citopatogénico. Si era EEV nunca lo sabremos aunque sí presumimos que lo fuera porque dichos ratones recibieron la picadura de mosquitos infectados por EEV. A pesar de los resultados imperfectos de estos ensayos de transmisión nos creemos autorizados a conceptuar que Ps. confinnis es un buen vector de EEV subgrupo ID en las condiciones de nuestro experimento, cuando se han infectado sobre hamsters con viremias altas y tienen más de 10 días de período de incubación extrínseco.

Es interesante notar que Psorophora confinnis se ha considerado como buen vector natural de cepas epizoóticas; sería esta la primera vez que se observa que puede ser también buen vector de virus enzoótico, por lo menos en condiciones experimentales.

\section{SUMMARY}

Rates of transmission by bite of Psorophora confinnis mosquitoes to albino swiss mice were studied when the mosquitoes were fed upon hamster and Proechimys hendei with different virus content of an enzootic strain (ID) of venezuelan equine encephalitis virus.

When the mosquitoes were fed upon hamster with virus in high concentration (7.5 dex in $0.1 \mathrm{ml}$ of serum, 6.5 in $0.1 \mathrm{ml}$ of serum) the mosquitoes infection and transmission rates were high.

However, when the Ps. confinnis mosquitoes were fed upon Proechimys hendei with virus in low concentration (1.4 dex in $0.1 \mathrm{ml}$ of serum, 2.6 in $0,1 \mathrm{ml}$. of serum) the mosquitoes infection rates were low and no transmission ocurred.

When the Proechimys hendei virus concentration was 4.4 . dex in $0.1 \mathrm{ml}$. of serum the mosquitoes infection rates increased and virus was transmitted.

These results suggest that Psorophora confinnis is a species of mosquitoes with a high threshold infection to this particular VEE enzootic strain.

\section{AGRADECIMIENTOS}

Al doctor HERNANDO GROOT, Jefe del Grupo de Virología del Instituto Nacional de Salud, por su constante ayuda en la revisión del trabajo y corrección del manuscrito. A la señora Alcira Díaz, por la transcripción del texto. 


\section{BIBLIOGRAFIA}

1. Morales, A., Romero, M., Olano, V.A., Calvache de D. Demostración del virus de la encefalitis equina venezolana, tipo enzoótico en la hemolinfa de mosquitos Psorophora confinnis infectados por vía oral. Biomédica 1982; 2 (3) : 111.

2. Olano, V.A., Morales, A. Colonización de una cepa de Psorophora (Grabhamia) confinnis (Arribalzaga, 1891) en Colombia, Biomédica 1982; 1 (2) : 12.
3. Reed, J. L., Muench, H.A. A simple method of estimating fifty per cent end points. Am. J. Hyg 1938: 27: 493.

4. Haldane J.B.S. Dex or "Order of Magnitude"? Nature 1960; (4740): 879 .

5. Sever, J.L. Aplication of a microtechnique to viral serological investigations. J. Inmunol 1962; 88: 320 . 